486. スボーツ社会学の研究方法に間する研究

広 島 大 学 $O$ 三好 喬, 三宅 清香
岡山県立短期大学
神 文 雄

E. Jok1: Medical Sociology and Cultural Anthropology of Sport and Physical Education (1964) に扰ける Medical Sociology of Sport を研究方法の 立場から考察する.これは，1952 年のヘルシンキにお。 ける第 15 回オリンピックゲームの一つの分析で，競技 成績を一定の公式より算出し，それを，次の観点から関 係つけるものである，即ち，世界の地理と人口，女子の オリンピック競技. 年令と競技成綪. 国の大さ. 気侯.

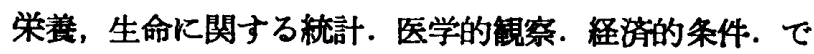
ある.

掫要 一定の公式より得点化し，それを基礎として， Participation (奇加者数), Point Share (得点数), Participation Rate (人口 100 万に対する去加者数), Point Rate (人口100万に対与る得点数)，Point Level （劫加者の平均得点数）の概念を定め，それを，上にあ けた観点と関係つける.

1. 世界の地理と人口. Point Share では, アメリ
カ,ソビェットが事めで, Point Rate からみれ ば.必らずしす両国はすぐれているとい充ない，又，フ フリカ，アジフの人口は多いが成績はよくない，これ は，社会的，政治的拉くれである.

2. 女子のオリンピック競技. 女子の夌加者が多く， 成績のすぐれているところは，女子の社会的地位が高 く，参加者が少く，成績のよくないところは，死亡率， 幼児死亡率が高い，又，女子の競技への丟加をはばんで いたのは，女子競技への生理的，社会的偏見やタブーで ある。

3. 経消的年件，程消数型からみて，経消的にすすん でいるところは，参加者も多く，競技成嚗もよい，又， 一人当りの所得からみても，所得の高いところは，去加 者も多く，競技成績もすぐれている.

まとめ 以上の Jokl のオリンピック競技の分析の角 度は，いろいろの批判はあるが，医学的立場から，一つ の文化様式をとらえ，それとスポーツの関連をとらえよ らとする，スボーツ社会学における一つの研究方法を提 示している意味で有意義なるのといえよう.

\section{7. 体育镸良校卒業生の追踦调查}

千葉大学下平翅 雄

日本医学会の「健康の度学」部門で「小学校時代体格 のよかつた者はど，早死しやすい」との報告がなされ た. 非常に気にかかることである．例年保健体育優良校 として数校表暗しているが，果して同校の卒業生か2,30 年後に健康な生活を送つているであろらか，集団として 観察した時, 是等の卒業生の体はどらなつているか，本 調査を試みた所以である。

喟亘の対奥は 千葉県市原市，戸田小学校を摆んだ。 同校は昭和初期より熱心な指導者と父兄の協力のあつた 擃村地带の学校である. 前校長多賀四郎先生及び宮田淳 先生の御協力を頂いて本調查を進めた，調査方法はアン ケートによつた。沿和 10 年度〜19 年度卒業生, 474 名 に発送し，63 通の回答を得た。返送 37 通，戦死 10 名， 病死 10 名であり，回収は意外に悪い。

倜查项目は 職業, 体格, 健康, 環境, 生活, 体力, 健康についての留意点, 死亡者の有無, の8 項目であ る.

集計の結果は表一で，表中身長增加は小学校 6 年次測
定値と現在との差である.

健は 63 名 60 名，不健康は僅か 3 名である。「健」と は次の様に規定した。

1. 最近一年間医師及び荬科医師の診療を受けたこと がない.

ロ.イロには該当しないが，病気になつた感じがした が、休についたり，業務を中止したりしたことがな w.

八. 外傷で 3 日以内での治瘜

結果として 子供か 2,3 人で適当な家に住 み, 领酒。 唤煙も程々にし，毎日好る湯に入谷し，千後 10 時前に 就床，7，8時間の睡眠をとる健全な生活を営んでいると 云える。

第二表は小学校在学 (6 年) の体育評価で甲（偍）と 乙（良）とを比较したもの。

第三表は都市居住者と農村居住者とを比較したもので ある. 晌病死者 10 名と不健と報告された 3 名の 6 年次 を比較すると体格では大きい者，評価では乙，病欠席の ある者がやや多くなつている，併し，例数が少いのでど うこう断言することは勿論できるるのではない。 